DOI https://doi.org/10.18551/rjoas.2021-01.13

\title{
MINERALOGICAL CHARACTE-RIZATION OF SOILS IN PLANTATION FOREST OF EAST KALIMANTAN, INDONESIA
}

\author{
Paranoan Ria Rachel ${ }^{*}$ \\ Faculty of Agriculture, University of Mulawarman, East Kalimantan, Indonesia \\ Kustiawan Wawan, Marjenah, Hartati Wahjuni, Syahrinudin, Sukartiningsih \\ Laboratory of Budidaya Hutan, Faculty of Forestry, University of Mulawarman, \\ East Kalimantan, Indonesia \\ Sudarmadji Triyono \\ Laboratory of KTAL, Faculty of Forestry, University of Mulawarman, \\ East Kalimantan, Indonesia \\ *E-mail: rachelria paranoan@yahoo.co.id
}

\begin{abstract}
Soil minerals including primary mineral and (secondary) clay mineral play an important role which has greatly contributed in determining the properties of soils and availability of soil nutrient reserve in soil. The objective of the study was to identify of clay minerals and primary minerals (sand fraction) at forest plantation area in East Kalimantan, Indonesia. The mineralogical composition of fine sand fraction of soils was identified using a polarizing microscope (PM). The mineralogical composition of clay fractions was determined using $X$ ray diffraction analysis (XRD). The research plot is circular with an area of 0.05 ha and a radius of $12.6 \mathrm{~m}$. Four soil sample from four plots collected for soil mineral analysis. The results showed that the clay fraction in plot $A 45$ has moderate amounts of kaolinite and vermiculite, trace amounts of goethite and illite. Plot A 34 was dominated by kaolinite, small amounts of vermiculite, trace amounts of illite. Plot A 36 was dominated by kaolinite, small amounts of vermiculite and illite, trace amounts of goethite. Plot A 33 was dominated by kaolinite small amounts of vermiculite and quartz. Compositions of Sand fraction at study area were dominated by resistant minerals (quartz).
\end{abstract}

\section{KEY WORDS}

Quartz, vermiculite, primay minerals, illit, clay minerals, kaolinite, industrial plantation forest.

Minerals are the main constituent elements of soil and play an important role in determining the chemical and physical properties of soil (Prastyo et al. 2004; Anda, et al. 2012). Minerals in the soil can be differentiated into primary minerals (fine sand fraction) minerals and secondary minerals or minerals from clay fraction (Prasetyo et al. 2004).

In general, the management of plants that continuously produce wood with fast growing plants that require a lot of nutrients will increase the depletion of large amounts of nutrients, this is closely related to land productivity, including efforts to increase land fertility by recognizing its potential presence nutrient reserve through the identifications of primary minerals and clay (secondary) minerals which greatly affect soil properties. So that it can help in formulating strategies for increasing soil productivity in industrial plantation forest location.

To determine the level of nutrient reserves of a soil type it is necessary to analyze primary mineral composition from the soil. Considering the importance of clay minerals, it is necessary to know the type of dominant clay minerals in order to further interpret the potential of soil resources and land capabilities (Munir, 1995). 
Based on research studied, the clay mineral has been identified in East Kalimantan (Ohta, et al., 1992; Prasetyo et al., 2001). Nevertheless, there is still little information of mineral found in plantation forest industry, Sebulu Subdistrict, East Kalimantan.

The purpose of this study was to identify primary minerals and clay minerals at plantation forest industry in East Kalimantan, Indonesia.

\section{METHODS OF RESEARCH}

The study was conducted at Industrial Plantation Forest, Sebulu-sub distric, East Kalimantan, Indonesia from March to July 2020. The research plot is circular with an area of 0.05 ha and a radius of 12.6 m (Syahrinudin, 1997; Syahrinudin, 2005; Mackenzen, 1998). Soil samples were taken from 4 plots for primary mineralogical analysis consists of $500 \mathrm{~g}$ from each sample form selected horizon and for clay mineral analysis consists of $500 \mathrm{~g}$ from each sample from selected horizon. The mineralogical compositions of sand fractions of soils were analyzed at using a polarizing microscope (PM). Mineralogical analysis to determine clay mineral composition was carried out using X-ray diffractometer (XRD), clay treatments, i.e., $\mathrm{Mg}$ then heated $550^{\circ} \mathrm{C}$.

\section{RESULTS AND DISCUSSION}

Based on sand fraction (primary minerals) analysis using polarizing microscope, the composition of primary minerals in sand fraction of soils is given in Table 1 . The resistant minerals at plot A45 was dominated by quartz (96\%). Composition of sand fraction minerals at plot A34 was dominated by quartz mineral (85\%), plot A36 was dominated by quartz mineral $(72 \%)$ and plot $A 33$ was dominated by quartz mineral $(92 \%)$. This indicates that the dominance of quartz minerals means that there is no potential for nutrient reserves. If the soil is dominated by quartz (resistant mineral), the soil is considered poor in nutrients (Tafakresnanto and Prasetyo, 2001).

Table 1 - Mineralogical Composition of fine sand fractions (50 -250 $\mu \mathrm{m})$

\begin{tabular}{|l|l|l|l|l|l|l|l|l|l|l|l|l|l|l|l|}
\hline Plot & $\mathrm{Op}$ & $\mathrm{Zi}$ & $\mathrm{Qt}$ & $\mathrm{Wm}$ & $\mathrm{Rf}$ & Konkresi Besi & $\mathrm{Lm}$ & $\mathrm{An}$ & $\mathrm{Lb}$ & $\mathrm{Bw}$ & $\mathrm{An}$ & $\mathrm{Or}$ & $\mathrm{Hb}$ & $\mathrm{Vg}$ & Total \\
\hline A45 & $\mathrm{sp}$ & 3 & 96 & $\mathrm{Sp}$ & 1 & - & - & - & - & - & - & - & - & - & 100 \\
\hline A34 & 9 & 4 & 85 & $\mathrm{Sp}$ & 2 & $\mathrm{sp}$ & - & $\mathrm{sp}$ & - & - & - & - & - & - & 100 \\
\hline A36 & 3 & 3 & 72 & 17 & - & 5 & - & - & - & - & - & - & - & - & 100 \\
\hline A33 & 2 & - & 92 & 1 & 5 & - & - & $\mathrm{sp}$ & - & - & - & - & - & - & 100 \\
\hline
\end{tabular}

Note:Op=opaque, $Z i=z i r c o n, Q t=q u a r t z, W m=$ weathered mineral, $R f=$ rock fragment, $L m=l i m o n i t e, A n=a n a t a s, L b=l a b r a d o r i t e$,

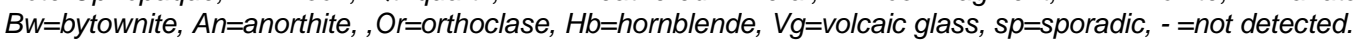

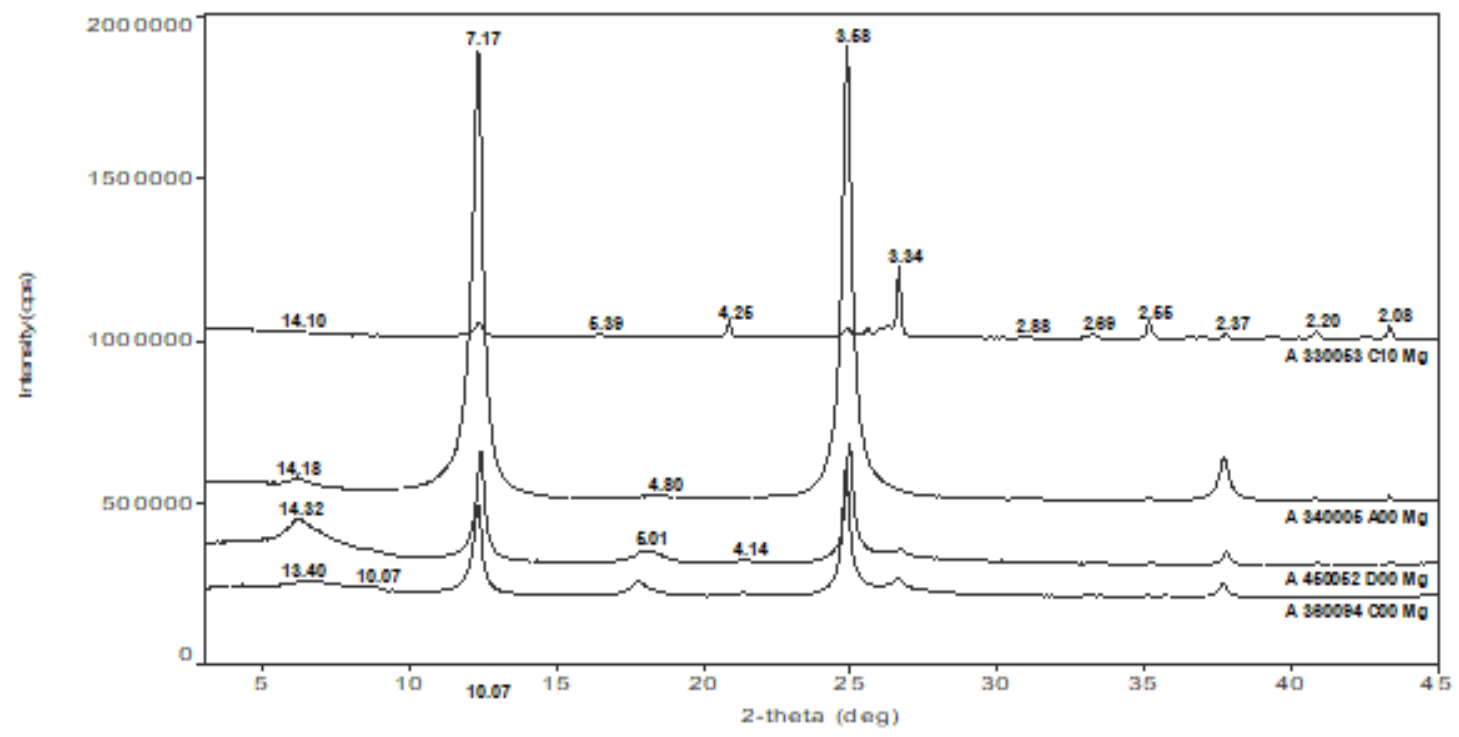

Figure 1 - X-ray diffraction patterns of the clay fraction of the soil treated with $\mathrm{Mg}$ 
The XRD patterns of clay fraction are illustrated in Fig.1. The XRD patterns of clay fractions from selected horizon of four plots indicated the presence of kaolinite, vermiculite, illite minerals in soils. The kaolinite mineral is characterized by the peak at $7.17 \AA$ on $\mathrm{Mg}$ saturated treatment. The peak of kaolinite and goethite minerals disappeared after heating treatment at $500^{\circ} \mathrm{C}$.

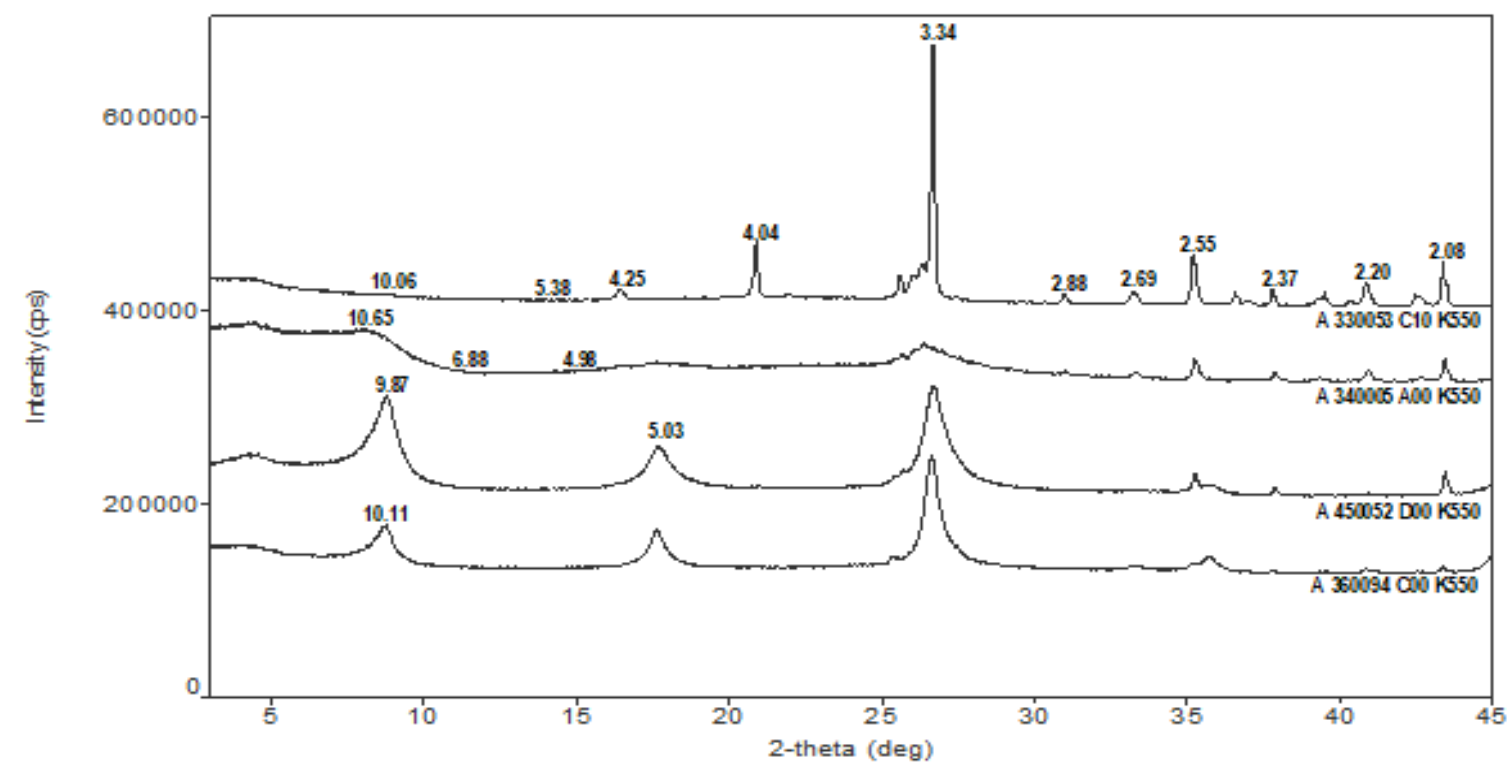

Figure 2- X-ray diffraction patterns of the clay fraction of the soil heated $550^{\circ} \mathrm{C}$

Table 2 - Composition of clay fraction

\begin{tabular}{|l|l|l|l|l|l|l|l|}
\hline No & Plot & Smectite & Kaolinite & Goethite & Vermiculite & Illite & Quartz \\
\hline 1 & A45 & - & ++ & $(+)$ & ++ & $(+)$ & - \\
\hline 2 & A34 & - & +++ & - & + & $(+)$ & - \\
\hline 3 & A36 & - & +++ & $(+)$ & + & + & - \\
\hline 4 & A33 & - & +++ & - & + & - & + \\
\hline
\end{tabular}

Note: $++++=$ predominant,$+++=$ dominant,$++=$ moderate,$+=$ small, $(+)=$ trace $-=$ not detected .

Clay minerals (secondary minerals) of soils all plots presented in Table 2 . There are moderate amounts of kaolinite and vermiculite, trace amounts of goethite and illite in plot A45. Composition of clay mineral in plot A34 dominated by kaolinite, small amounts of vermiculite and trace amounts of illite. The clay fraction of plot A36, dominated by kaolinite mineral, small amounts of vermiculite and illite, and trace amounts of goethite. Composition of clay mineral at plot A33 dominated by kaolinite, and small amounts of vermiculite and quartz.

\section{CONCLUSION}

Clay mineral compositions presented in all plots. Clay minerals composition of soils was dominated by kaolinite minerals. The dominance of resistant minerals at study area in forest plantation, sub-distric sebulu, East kalimantan dominated by quartz mineral in all plots. indicated that the soils have no potential reserved nutrients or soil has low fertility.

\section{REFERENCES}

1. Anda, M., Mulyani, A., Surapto. 2012. Mineralogical and Characterization and Chemical Properties of Soils as a Consideration for Establishing Sustainable Soil Management Strategies. Indonesian Journal of Agricultural Science 13(2):54-67. 
2. Mackensen, J. 1998. Untersuchung zur nachhaltigen Nährstoffversorgung in schnellwachsenden Plantagensystemen in Ost-Kalimantan, Indonesien-ökologische und ökonomische Implikationen. Göttinger Beiträge zur Land-und Forstwirtschaft in den Tropen und Subtropen. 127.

3. Munir, M. 1995. Geologi \& Mineralogi Tanah. Pustaka Jaya. ISBN: 979-419-146-9.

4. Prasetyo, B.H., J.S. Adiningsih, K. Subagyono, \& R.D.M. Simanungkalit. 2004. Mineralogi, Kimia, Fisika and Biologi Lahan Sawah. HIm. 36-50. Dalam F. Agus (Wd.) Lahan Sawah and Teknologi Pengelolaanya. Pusat Penelitian Tanah and Agroklimat, Bogor.

5. Prasetyo, B.H.,Suharta,N.,Subagyo,H.,Hikmatullah. Chemical and Mineralogical Properties of Ultisols of Sasamba Area,East Kalimantan. Indonesian Journal of Agricultural Science 2(2): 37-47.

6. Pramuji \& Bastaman.M. (2009). Teknik Analisis Mineral Tanah Untuk Menduga Cadangan Sumber Hara. Buletin Teknik Pertanian. Vol. 14.N0.2.80-82.

7. Ohta, S., Effendi,S.,Tanaka,N., Miura S. 1992. Characteristics of Major Soils Under Lowland Dipterocarp Forest in East Kalimantan, Indonesia. PUSREHUT Special Publication No.2.

8. Syahrinudin. 1997. The Role of Undergrowth on Timber Estate of Eucalyptus deglupta in East Kalimantan. [Thesis]. The Master of Science Degree in Tropical Forestry and Ecology Georgia Augusta University, Gottingen. [Germany].

9. Syahrinudin. 2005. The potential of oil palm and forest plantations for carbon sequestration on degraded land in Indonesia. [Disertation]. Zentrum fur Entwicklungsforschung Center Development Research, University of Boon. [Germany].

10. Tafakresnanto, C. and B.H.Prasetyo.2001. Peranan data mineral tanah dalam menunjang interpretasi sumber daya tanah. Jurnal Tanah and Air 2(1): 47-56. 